\title{
PERANCANGAN APLIKASI PENGOLAHAN DATA DANA SEHAT PADA RUMAH SAKIT UMUM MUHAMMADIYAH METRO
}

\author{
KHOLIK HIDAYATULLOH ${ }^{(1)}$, M. KOMARUDIN MZ ${ }^{(2)}$, ASIH SUTANTI (3) \\ Fakultas IImu Komputer Universitas Muhammadiyah Metro \\ Jl. Gatot Subroto, Yosodadi, Metro Timur, Kota Metro
}

\begin{abstract}
Abstrak
Tugas Akhir ini merupakan hasil dari analisis dan observasi yang penulis lakukan terhadap sistem informasi yang sedang berjalan dan hasil perancangan yang baru dari Perancangan Aplikasi pengolahan Data Dana Sehat Pada RSU Muhammadiyah Metro. Kondisi saat ini yang ada di RSU Muhammadiyah Metro dalam mengolah dana sehat mempunyai masalahmasalah seperti pencatatan anggota masih buku besar akibat nya data bisa ganda ataupun selip, cetak laporan menggunakan exel dapat tidak akurat karena bisa dokumen ganda akibat nya jumlah anggota bisa salah. Penelitian ini menghasilkan rancangan database/basis data yaitu tabel pendaftaran pasien dana sehat, tabel pasien dana sehat, tabel rekam medis dana sehat. Entity Relationship Diagram (ERD) dan relasi tabel. Rancangan antar muka input dan output yaitu tampilan login, menu utama, tampilan input pasien dana sehat, input rekam medis pasien dana sehat, serta tampilan laporan pasien dana sehat berdasarkan periode bulanan. Dengan adanya rancangan aplikasi pengolahan data dana sehat diharapkan dapat mempermudah dalam pencarian data meliputi: calon pasien yang mendaftar, daftar pasien, serta data rekam medis pasien. Mempermudah dan mempercepat dalam pembuatan laporan pertanggal pasien dana sehat RSU Muhammadiyah metro. mengurangi terjadinya kerangkapan/data pasien ganda, mengurangi kesalahan dalam perhitungan jumlah pasien.
\end{abstract}

Kunci: Aplikasi pengolahan data, Dana Sehat, Borland Delphi 7, RSU Muhammadiyah metro

\section{PENDAHULUAN}

\subsection{Latar Belakang Masalah}

Perkembangan teknologi yang yang disertai dengan perkembangan ilmu pengetahuan disegala bidang mendorong hampir semua instansi kedalam teknologi yang berbasis komputer. Adanya komputer diyakini akan banyak membantu manusia untuk tujuan efisiensi biaya dan efektifitas kerja. dengan semua kelengkapan yang ada di komputer telah dapat memberikan segala informasi dengan tingkat akurasi yang tinggi, sehingga pemanfaatannya semakin meluas tidak hanya di bidang teknologi informasi saja, tetapi bidang ekonomi, hiburan, keamanan, bisnis, juga termasuk penggunaan dibidang pendidikan dan kesehatan. Secara berangsur manusia mengalihkan pekerjaan yang tadinya dilakukan secara manual ke komputer, salah satunya adalah di dunia pelayanan kesehatan. Dengan menggunakan teknik komputerisasi diharapkan dapat meningkatkan efisiensi dan kualitas pelayanan. RSU Muhammadiyah Metro adalah RS swasta kelas D. RS ini telah dimulai sejak tahun 1967. Pada tahun itu pimpinan cabang muhammadiyah lampung tengah di metro telah memiliki azin operasional rumah sakit. Pendiri RSU Muhammadiyah kembali diamatkan oleh musyawarah daerah Muhammadiyah II kota metro periode 2005-2010. Musyawarah daerah mengamantkan kepada pengurus untuk mendirikan RSU Muhammadiyah Metro sebagai sarana dan media dakwah dengan cara mengembangkan balai pengobatan yang sudah ada atau dengan mendirikan rumah sakit yang baru. Dari berbagai studi kelayakan dan beberapa analisa selama beberapa bulan, panitia pendiri RSU Muhammadiyah Metro yang diketuai Drs.Hi.Amin HS, menetapkan lokasi di 
jalan Soekarna Hatta no.42(bekas Rumah Sakit "Amanah"). sebagai lokasi yang paling layak dan tepat untuk didirikan RSUD Muhammadiyah Metro. Diatas tanah seluas $8005 \mathrm{~m}^{2}$. Saat ini telah terbangun gedung seluas $\pm 2000 \mathrm{~m}^{2}$ dengan berbagai fasilitas. Berkat kegigihan dan keuletan dari berbagai pihak saat ini Rsu Muhammadiyah Metro kini telah siap melayani pasien. RSU Muhammadiyah Metro mulai beroperasi sejak 1 januari 2008 dan diresmikan oleh ketua pp Muhammadiyah (Bapak Prof Dr. Din Syamsudin, MA) dengan dihadiri oleh drg.Naedial Roisdal(Staf Ahli Menkes) Ir.MS Joko Umar said, MM (Asisten IV Sekrop Lampung). Hi. Lukman Hakim, SH.MM (Wali Kota Metro) pada tanggal 22 Januari 2008 RS ini selain mempunyai beberapa layanan juga mengelola progam dana sehat yang diperuntukan untuk masyarakat. Dimana sejarah pelaksanaanya upaya kesehatan dana sehat masyarakat sebenarnya dilatarbelakangi oleh upaya kegiatan gotong royong atau mapalus dukan yang dikenal dengan istilah mapalus sosial duka, dimana setiap ada anggota masyarakat yang mengalami kedukaan, setiap keluarga sukarela memberikan sumbangan uang maupun bahan makanan. Kemudian mapalus sosial duka ini dilanjutkan dengan kegiatan mapalus pembangunan untuk membangun rumah sehat, pagar halaman dan mapalus kebun. Dimulai tahu 1982 rukun ini memulai usaha dana sehat setiap keluarga wajib membayar iuran dana sehat setiap bulannya. Ketika ada yang sakit, pengurus rukun mengeluarkan dana sehat untuk membiayai anggota yang sakit, mulai biaya rawat jalan di Puskesmas, hingga rawat inap di Rumah Sakit. Misi dari program D-III Manajemen Informatika adalah menyelenggarakan pendidikan, penelitian dan pengabdian kepada masyarakat berdasarkan nilai ke Islaman dengan berorientasi pasar dan didukung oleh sarana dan prasarana dalam upaya membentuk sumber daya manusia yang menghayati dan mengembangkan ilmu pengetahuan teknologi dan seni, sumber daya manusia yang memiliki wawasan dan sikap inisiatif, inovatif dan produktif, sumber daya manusia yang mampu memelihara dan mengembangkan bidang keahlian secara amanah, jujur dan bertanggung jawab, lulusan yang memenuhi kebutuhan masyarakat dan niat masyarakat untuk memasuki program studi D-III Manajemen informatika. Seperti firman Allah surat Yunus Ayat 57 yang berbunyi:

Artinya: "Hai manusia, sesungguhnya telah datang kepadamu pelajaran dari Tuhanmu dan penyembuh bagi penyakitpenyakit (yang berada) dalam dada dan petunjuk serta rahmat bagi orang-orang yang beriman." Rumah Sakit Umum Muhammadiyah Metro saat ini memiliki program khusus di bidang kesehatan yakni Dana Sehat, namun Dana Sehat yang ada di RSU Muhammadiyah Metro khusus ditujukan untuk pihak pindidikan yakni TK, SD, SMP, SMA dan sederajat. Untuk sistem yang sedang berjalan saat ini pengolahan Dana Sehat seperti pendaftaran dan penulisan anggota masih manual dengan menggunakan buku besar. Namun dalam pembuatan kartu anggota dan pembuatan laporan sudah menggunakan Microsoft Exel. Adapun dalam pengolahan terdapat masalah yang ditemui: 1) terkadang lupa dalam mengarsipkan data anggota sehingga menyulitkan karyawan dalam pencarian datanya, 2) dalam pengolahan data masih dengan cara menulis sehingga memakan banyak waktu dan rentan terjadi kesalahan. Berdasarkan permasalahan yang ditemui pada tempat penelitian sesuai dengan uraian diatas, maka penulis mengajukan judul Tugas Akhir dengan judul "PERANCANGAN APLIKASI PENGOLAHAN DATA DANA SEHAT PADA RSU MUHAMMADIYAH METRO".

\section{KAJIAN PUSTAKA}

\subsection{Tinjauan Pustaka}

Tinjauan pustaka diambil dari beberapa buku, jurnal dan artikel yang berhubungan dengan penelitian ini adalah sebagai berikut:

a. Penelitian yang dilakukan oleh Ardik Eko Setiawan (2016) " ANALISIS DAN PERANCANGAN SISTEM INFORMASI AKADEMIK BERBASIS WEB", Penelitian ini membahas tentang 
pengembangan sebuah Sistem Informasi Berbasis Web untuk pengolahan data Kartu Hasil studi dan Kartu Rancangan Studi. Dimana dalam membangun sistem ini digunakan alat bantu pengembangan sistem yaitu Data Flow Diagram (DFD), Context Diagram, Entity Relationship Diagram (ERD) dan Flowchart serta dengan menggunakan bahasa pemrograman PHP dan HTML dan MySQL sebagai databasenya.

b. Penelitian yang dilakukan oleh Reza Milady Fauzan (2008) "Penelitian ini membahas tentang pengembangan menganalisa dan membuat aplikasi sistem pemesanan produk berbasis Web pada CV Hanif Niaga Group yang dapat menyajikan informasi yang dibutuhkan oleh konsumen. Dengan sistem ini Pihak CV Hanif Niaga Group dapat membangun sebuah sistem pemesanan produknya berbasis internet yang bisa menghilangkan keterbatasan jarak dan waktu.

\subsection{Landasan Teori}

\subsubsection{Perancangan Sistem}

Perancangan adalah penggambaran, perencanaan dan pembuatan sketsa atau pengaturan dari berbagai elemen yang terpisah ke dalam satu kesatuan yang utuh dan berfungsi (Syifaun Nafisah, 2003: 2). Pengertian perancangan menurut para ahli diantaranya adalah :

a) Menurut Varzello / John Reuter III perancangan adalah tahap setelah analisis dari siklus pengembang sistem : Pendefinisian dari kebutuhankebutuhan fungsional dan persiapan untuk rancang bangun implementasi : "Mengembarkan bagaimana suatu sistem dibentuk".

b) Menurut John Buch \& Gary Grudnitski perancangan dapat didefinisikan sebagai penggambaran, perencanaan dan pembuatan sketsa atau pengaturan dari beberapa elemen yang terpisah ke dalam satu kesatuan yang utuh dan berfungsi.

c) Menurut George M. Scott perancangan adalah menentukan bagaimana sistem akan menyelesaikan apa yang mesti diselesaikan ; tahap ini menyangkut mengkonfigurasikan dari komponenkomponen perangkat lunak dan perangkat keras dari suatu sistem, sehingga setelah instalasi dari sistem akan benar-benar memuaskan rancang bangun yang telah ditetapkan pada akhir tahap analisis sistem.

Pada saat membuat sistem membuat sebuah sistem yang akan digunakan pada suatu perusahaan, setiap pengembang aplikasi diharuskan membuat sebuah rancangan dari sistem yang ingin dibuat. Rancangan ini bertujuan untuk memberi gambaran umum dari sistem yang akan berjalan nantinya kepada setiap stakeholder. Terdapat pula teori-teori mengenai pengertian perancangan sistem menurut para ahli diantaranya adalah :

a) Menurut Satzinger, Jackson dan Burd (2012 : 5) perancangan sistem adalah sekumpulan aktivitas yang menggambarkan secara rinci bagaimana sistem akan berjalan. Hal itu bertujuan untuk menghasilkan produk perangkat lunak yang sesuai dengan kebutuhan user.

b) Menurut Kenneth dan Jane (2006 : G12) perancangan sistem adalah kegiatan merancang dan menentukan cara mengolah sistem informasi dari hasil analisa sistem sehingga sistem tersebut sesuai dengan requirement.

c) Menurut O'Brien dan Marakas (2009: 639) perancangan sistem adalah sebuah kegiatan merancang dan menentukan cara mengolah sistem informasi dari hasil analisa sistem sehingga dapat memenuhi kebutuhan dari pengguna termasuk diantaranya perancangan user interface, data dan aktivitas proses. Dari beberapa teori-teori diatas dapat disimpulkan bahwa perancangan sistem adalah proses perancangan untuk merancang suatu sistem baru atau memperbaiki suatu sistem yang telah ada sehingga sistem tersebut menjadi lebih baik dan biasanya proses ini terdiri dari proses merancang input, output dan file.

\subsection{Pengertian Aplikasi}

Aplikasi merupakan suatu subkelas perangkat lunak komputer yang memanfaatkan kemampuan komputer langsung untuk melakukan suatu tugas yang diinginkan pengguna. Biasanya dibandingkan dengan perangkat lunak sistem yang mengintegrasikan berbagai kemampuan komputer. Terdapat 
beberapa teori yang mendefinisikan Aplikasi yang dikemukakan oleh beberapa para ahli, diantaranya adalah :

a) Menurut Jack Febrian dalam buku kamus yang berjudul komputer dan teknologi informasi (2007) Aplikasi adalah program siap pakai, program yang direka untuk melaksanakan suatu fungsi bagi pengguna atau aplikasi yang lain.

b) Menurut Sutarman dalam bukunya yang berjudul pengantar teknologi (2009: 147) Aplikasi merupakan programprogram yang dibuat oleh suatu perusahaan komputer untuk para pemakai yang beroperasi dalam bidang umum, seperti pertokoan, komunikasi, penerbangan, perdagangan dan sebagainya.

c) Menurut Hendrayudi dalam bukunya vb (2009 : 143) Aplikasi adalah kumpulan perintah program yang dibuat untuk melakukan pekerjaanpekerjaan tertentu khusus). Jadi Aplikasi merupakan sebuah program yang di buat dalam sebuah perangkat lunak dengan komputer untuk memudahkan pekerjaan atau tugas-tugas tertentu seperti penerapan, penggunaan dan penambahan data yang dibutuhkan.

\subsection{Pengolahan Data}

Data berasal dari kata "Datum" yang berarti fakta atau bagian dari fakta yang mengandung arti yang dihubungkan dengan kenyataan yang dapat digambarkan dengan simbol, angka, huruf dan sebagainya. Pengertian data menurut Vercellis (2009:6) adalah data merupakan sebuah representasi fakta yang tersusun secara terstruktur. Selain deskripsi dari sebuah fakta, data dapat pula merepresentasikan suatu objek sebagaimana dikemukakan oleh Wawan dan Munir (2006: 1) bahwa "Data adalah nilai yang merepresentasikan deskripsi dari suatu objek atau kejadian. Data menurut Drs.Jhon J.Longkutoy (1996: 69) mengatakan bahwa "data event)." adalah suatu istilah majemuk dari fakta yang mengandung arti yang dihubungkan dengan kenyataan, simbol, gambar, angka, huruf yang menunjukan suatu ide, objek, kondisi atau situasi dan lainnya". Dari beberapa pengertian diatas maka dapat diambil kesimpulan bahwa "data adalah merupakan fakta atau bagian dari fakta yang belum tersusun yang mempunyai arti yang dihubungkan dengan kenyataan yang benar-benar terjadi, fakta dapat dinyatakan dengan gambar (grafik), kata-kata, angka, huruf dan lain sebagainya".

Pengelolaan data adalah segala macam pengelolaan terhadap data atau kombinasi- kombinasi dari berbagai macam pengelolaan terhadap data untuk membuat data itu berguna sesuai dengan hasil yang diinginkan dapat segera dipakai. Menurut Jogiyanto H.M "Pengelolaan Data adalah manipulasi dari data ke dalam bentuk yang lebih berguna berarti". Dengan demikian dapat disimpulkan bahwa "Pengolahan Data merupakan kegiatan yang dilakukan dengan menggunakan masukan berupa data dan menghasilkan informasi yang bermanfaat untuk tujuan sesuai dengan yang direncanakan".

\section{METODE}

Metode Penelitian adalah kesatuan metode-metode, prosedur, konsepkonsep. Dalam memperoleh data guna menyusun Tugas Akhir, Penulis menggunakan metode-metode yaitu sebagai berikut:

Studi Lapangan

Untuk mendapatkan data, penulis melakukan studi lapangan dengan menggunakan teknik:

a. Observasi (Pengamatan)

Observasi adalah metode pengumpulan data dengan cara pengamatan langsung kegiatan operasional yang berlangsung di Rumah Sakit Muhammadiyah Metro.

b. Interview (wawancara)

Interview adalah metode pengumpulan data dengan cara wawancara atau tanya jawab secara langsung dengan pegawai dana sehat yang bersangkutan dengan ini penulis melakukan wawancara secara langsung dengan "Ibu Hana" serta yang terkait.

c. Dokumentasi

Dokumentasi adalah metode pengumpulan data dengan cara mengumpulkan dokumen dan arsip yang dibutuhkan untuk penelitian. 
d. Studi Pustaka

Yaitu dengan cara mengumpulkan data dengan membaca buku dan mempelajari literatur yang berkaitan dengan masalah yang dihadapi.

\section{HASIL PENELITIAN DAN PEMBAHASAN}

Dari penelitian yang dilaksanakan pada Rumah Sakit Umum Muhammadiyah Metro telah didapatkan hasil dari penelitian dan pembahasan ialah sebagai berikut:

\subsection{Hardware}

Perangkat keras rancangan keras yang diisulkan untuk keperluan dalam system yang dirancang

1. Prosesor AMD dual-core

2. System 32 bit

3. Ram $2 \mathrm{gb}$

4. Hardisk $500 \mathrm{gb}$

5. Lcd 14.0"

\subsection{Software}

Dalam pembuatan aplikasi pengolahan data dana sehat RSU Muhammadiyah Metro dibutuhkan perangkat lunak untuk menjalankan dan mengoperasikan komponen Hardware, Software yang dibutuhkan.

1. Sistem operasi windows 7

2. Borland delphi

3. Database MySql

4. Xampp

\subsection{Brainware}

Untuk melaksanakan sistem yang sedang dirancang penulis perlu tim kerja yang memiliki keahlian dibidang masing-masing dimana dengan adanya tenaga yang memiliki keahlian diharapkan dapat mempercepat proses pengolahan data dana sehat adanya perangkat piker yaitu seorang operator.

\section{KESIMPULAN}

Berdasarkan hasil analisa yang penulis lakukan terhadap masalah yang terjadi terutama pada pengolahan data dana sehat maka dapat merancang aplikasi pengolahan data dana sehat. Sehingga dapat diambil beberapa kesimpulan sebagai berikut:

1. Berdasarkan perancangan aplikasi pengolahan data dana sehat dihasilkan rancangan login, rancangan input pendaftaran calon pasien dana sehat, rancangan input pasien dana sehat, rancangan input rekam medis pasien, serta rancangan laporan pasien dana sehat .

2. Dengan adanya rancangan aplikasi pengolahan data dana sehat dapat mempermudah dalam pencarian data meliputi: calon pasien yang mendaftar, daftar pasien, serta data rekam medis pasien.

3. Mempermudah dan mempercepat dalam pembuatan laporan pertanggal pasien dana sehat RSU Muhammadiyah metro.

\section{DAFTAR PUSTAKA}

[1] Burch John \& Gary Grundnitski, 1986, Information Systems Theory and Practice, John Wiley and Sons, New York

[2] Radit. (2012). Perancangan Sistem Informasi. Yogyakarta: Andi Offset.

[3] Shelly, G.B., \& Rossenbalt, H.J. (2012). System Analysis and Design 9th Edition. Boston: Course Technology

[4] (Scott, 2001). George M. Scott, PrinsipPrinsip Sistem Informasi Manajemen, RajaGrafindo Persada, Jakarta, 2001

[5] J. W. Satzinger, R. B. Jackson and S. D. Burd, Systems Analysis and esign in a Changing World, Sixth ed., 2011.

[6] Setiawan, Wawan. Dan Munir. (2006). Pengantar Teknologi Informasi : Basis Data, Bandung : Universitas Pendidikan Indonesia.

[7] Setiawan, Wawan. Dan Munir. (2006). Pengantar Teknologi Informasi : Sistem Informasi, Bandung : Universitas Pendidikan Indonesia

[8] John. J. Longkutoy. Pengenalan Komputer, Cetakan Keenam. PT. Mutiara Sumber Widya, Jakarta. 1989 